\title{
A new mineral fertilizer for cacti and other succulents cultivated in restricted artificial environments ${ }^{(1)}$
}

\author{
LUIZ ERLON ARAÚJO RODRIGUES ${ }^{(2)}$, LUIS CARLOS SOARES QUEIRES ${ }^{(3)}$
}

\begin{abstract}
The growing enthusiasm currently seen for the cultivation of ornamental plants has aroused interest in exotic plants, principally cacti and other succulents. Although they need little care when planted directly in the soil, they become vulnerable if growing in restricted environments that vary greatly from their natural habitats. In these cases, in addition to requiring more care with respect to illumination, watering and environmental temperature, it is also important to sprinkle them periodically with a mineral nutrient solution consisting of the macronutrients and micronutrients required for physiological growth and development. The excellent results obtained experimentally with the Schlumbergera truncata cactus, treated for 90 days with a mineral solution specifically prepared for this study and compared with the results obtained with the same species of plant watered with distilled or tap water, encourage us to propose this solution as a new mineral fertilizer for cacti and other succulents when cultivated in small, restricted spaces.
\end{abstract}

Keywords: ornamental plants; mineral nutrient solution; Cactaceae; S. truncata.

\section{RESUMO}

Novo fertilizante mineral para cactos e outras suculentas cultivadas em pequenos ambientes artificiais O crescente entusiasmo observado com o cultivo de plantas ornamentais tem despertado o interesse por plantas exóticas, principalmente de cactos e outras suculentas. Apesar de necessitarem poucos cuidados quando plantadas diretamente no solo, tornam-se vulneráveis se vegetam em ambientes restritos e muito diferentes dos seus hábitats. Nesses casos, além de maiores cuidados com a iluminação, irrigação e temperatura do ambiente, torna-se muito importante a rega periódica com uma solução nutritiva mineral composta de macronutrientes e micronutrientes envolvidos no crescimento e desenvolvimento fisiológicos. Diante dos resultados exuberantes obtidos, experimentalmente, com o cacto Schlumbergera truncata, tratado durante 90 dias com uma solução mineral especialmente preparada para este estudo e comparados com aqueles obtidos pelo mesmo tipo de planta irrigada com água destilada ou com água da torneira, propomos a referida solução como novo fertilizante mineral para cactos e outras suculentas, crescendo em ambientes pequenos e restritos.

Palavras chave: plantas ornamentais; solução mineral nutritiva; Cactaceae; S.truncata.

\section{INTRODUCTION}

Cacti are perennial, succulent, generally spiny plants of the Cactaceae family, represented by around 170 genera and 1500-2000 species and distributed throughout the Americas from Canada to Patagonia in Argentina (ROJASARÉCHICA and VASQUEZ-YANES, 2000). According to Castro (2008), there are around 40 genera and 200 species of this plant in Brazil, of which 24 genera and 88 species are found in the northeastern region. They belong to the Angiospermae class and constitute a very diverse group of species that have adapted evolutive and ecological responses that permit them to grow and reproduce in environments in which water is often scarce and temperatures range from 10 to $40{ }^{\circ} \mathrm{C}$. They range in size from $20 \mathrm{~m}$ (Carnegiea gigantea, Pachycereus pringlei, $P$. schottii) to as small as $0.5 \mathrm{~cm}$ in the case of the Blosfeldia liliputana from the Bolivian Andes (LONE et al., 2007).
When in their natural environment, the different members of the group of succulents are able to absorb various types of minerals present in the soil. As a result of the sporadic and unbalanced availability of these minerals in the various types of soil, some cacti and succulents only survive in their natural habitat. Nevertheless, they are able to grow and flourish when cultivated with regular, adequate fertilization (LESSA et al., 2009).

According to Epstein and Bloom (2006) there may be enormous variations in the chemical and biological complexities of the natural or artificial soils or microenvironments in which plants grow. The micro fauna and meso fauna present in the environment are directly affected by the richness of the mineral solutes and the abundant products of organic decomposition. After the organic compounds are mineralized, they, together with the preexisting mineral salts, will constitute the principal source of nutrients for plants.

\footnotetext{
(1) Trabalho recebido para publicação em 17/10/2013 e aprovado em 22/10/2014

(2) Bahiana School of Medicine and Public Health (EBMSP - FBDC), Rua Frei Henrique, 8, 40150-420 Salvador, Bahia, Brazil. erlon@svn.com.br

(3) State University of Bahia (UNEB), Campus II, Alagoinhas, Bahia. lqueires@yahoo.com.br
} 
Various other factors may directly affect the micro flora, micro fauna and meso fauna and, consequently affect plant nutrition, particularly humidity, insolation, temperature, $\mathrm{pH}$, the use of defense products and aeration. Practically all plants have mycorrhizae and bacteria in their roots that help mobilize nutrients for root absorption (RODRIGUES and QUEIRES, 1995). They also take advantage of the root excretions composed of amino-acids, sugars, hormones, vitamins and a great variety of organic acids that are used as a source of carbon and energy by these microorganisms which, in exchange, defend the space around the roots with antibiotics against pathogenic agents. According to Cornelio et al., (2007), the availability of soil mutants is considered one of the factors responsible for the resistance of plants to diseases. The more nourished and intense the micro fauna around the roots, the more resistant they are to attacks by pathogens. This important balance may be broken when plants are grown in restricted environments with different soil substrates, such as the case of the majority of ornamental plants (ROCHA et al., 2009).

Constant irrigation of these microenvironments with low-mineral water may, by lixiviation, lead to the reduction or even depletion of important nutrients that contribute to the hypo development and appearance of diseases in ornamental plants.

In view of the aforementioned facts and the difficulty in finding commercially available nutrient solutions containing primary and secondary macronutrients in addition to the primary micronutrients necessary for the physiological development of succulents and cacti, the purpose of this paper is to propose a special nutrient solution based on the studies of Rodrigues and Queires (1995) and Arnold and Mauseth (1999) to be used in plants cultivated in small, restricted environments.

\section{MATERIAL AND METHODS}

Three samples of the cactus $S$. truncata (also known as the May flower cactus), each consisting of three cladodes, similar, linked in sequence and removed from the same adult plant, were planted in single plastic pots seven centimeters in height and $10 \mathrm{~cm}$ in diameter, each containing $550 \mathrm{~g}$ of ground marble. This type of substrate was selected because it most closely resembles the natural habitat of the cactus and because it provides better control with respect to the supply of nutrients to the samples. Prior to being used, the substrate was washed several times in running water and boiled for an hour to sterilize the microorganisms. Each pot containing 8 holes of $5 \mathrm{~mm}$ in diameter was placed on a plastic dish three centimeters in height. Plants were watered every three days by capillarity, filling each dish separately with distilled water, tap water or with the nutrient solution specifically prepared for this experiment. The three samples of cactus were submitted to the same cultivation conditions, consisting of: temperature maintained at $22{ }^{\circ} \mathrm{C}$ in a temperature controlled environment, natural lighting during the day and environmental humidity. Figure 1 shows the three initial samples.

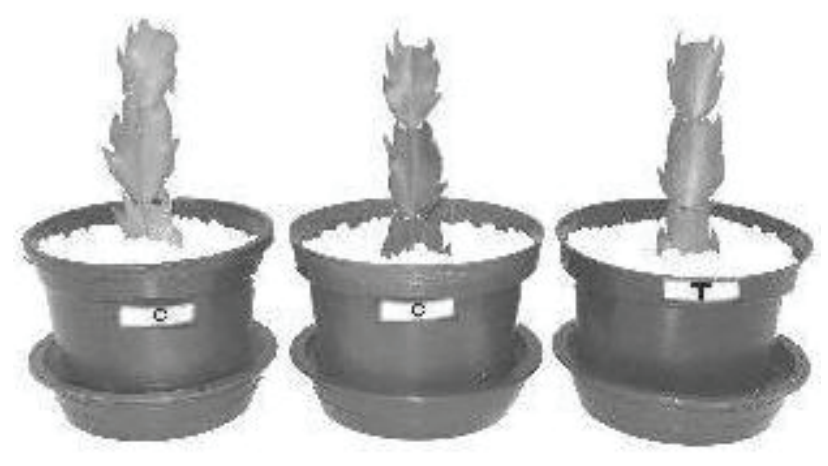

\section{Figure 1. The three samples of S. truncata at the beginning of experiments.}

Figura 1. As três amostras de $S$. truncata no início das experiências.

Special nutrient solution for cacti and other succulents

This solution consisted of three primary macronutrients, two secondary macronutrients and three micronutrients. Table 1 shows the guaranteed weight/weight concentrations (w/w\%) of the different contents of the concentrated solution. Immediately prior to use, this concentrated solution was diluted 400 times in distilled water and used as described. 
Table 1. Proposed formulation of the special nutrient solution for cacti and other succulents.

Tabela 1. Formulação da solução nutritiva especial para cactos e outras suculentas.

\begin{tabular}{|cccc|}
\hline Types of elements & Primary macronutrients & Secondary macronutrients & Micronutrients \\
\hline Nitrogen $(\mathrm{N})$ & $1 \mathrm{~g} / 100 \mathrm{~g}$ & $\mathrm{X}$ & $\mathrm{X}$ \\
\hline Phosphorus $(\mathrm{P})$ & $2 \mathrm{~g} / 100 \mathrm{~g}$ & $\mathrm{X}$ & $\mathrm{X}$ \\
\hline Potassium $(\mathrm{K})$ & $1 \mathrm{~g} / 100 \mathrm{~g}$ & $\mathrm{X}$ & $\mathrm{X}$ \\
Sulfur $(\mathrm{S})$ & $\mathrm{X}$ & $1 \mathrm{~g} / 100 \mathrm{~g}$ & $\mathrm{X}$ \\
Magnesium $(\mathrm{Mg})$ & $\mathrm{X}$ & $0,5 \mathrm{~g} / 100 \mathrm{~g}$ & $\mathrm{X}$ \\
Zinc $(\mathrm{Zn})$ & $\mathrm{X}$ & $\mathrm{X}$ & $0,2 \mathrm{~g} / 100 \mathrm{~g}$ \\
Copper $(\mathrm{Cu})$ & $\mathrm{X}$ & $\mathrm{X}$ & $0,05 \mathrm{~g} / 100 \mathrm{~g}$ \\
Boron $(\mathrm{B})$ & $\mathrm{X}$ & $\mathrm{X}$ & $0,02 \mathrm{~g} / 100 \mathrm{~g}$ \\
\hline
\end{tabular}

\section{Total chlorophyll measurement}

After 90 days of controlled growth, samples were removed in the form of similar fragments of tissue from the cladodes of the three plants, weighed and placed separately in beakers marked "distilled water", "tap water" and "nutrient solution". Next, they were chopped using scissors and homogenized in a Potter-Elvehjem tissue grinder containing five milliliters of an acetone/distilled water mixture (80/20 v/v, respectively) and immersed in melting ice. Immediately after homogenization, the samples were centrifuged at $900 \mathrm{~g}$ for 10 minutes at a temperature of $4^{\circ} \mathrm{C}$. The supernatants were removed and immediately measured by spectrophotometry at 645 and $663 \mathrm{~nm}$ for evaluation of total chlorophyll content in accordance with the technique described by Wellburn (1994).

\section{Total protein measurement}

Similar samples weighing approximately 500 milligrams were removed from the cladodes of the three plants and chopped separately into $5 \mathrm{~mL}$ of distilled water. Next, a sample representing each plant was homogenized separately in melting ice and immediately centrifuged at
$900 \mathrm{~g}$ for $10 \mathrm{~min}$ in a refrigerated centrifuge at a temperature of $4{ }^{\circ} \mathrm{C}$. The resulting supernatants were used to determine total protein levels using the Folin-biuret technique, modified by Rodrigues et al., (1989).

Determination of the dry weight and weight of the ashes of the cladodes and roots of the three plants evaluated in the study

After having been carefully removed from their pots, each plant was washed, particularly around the roots, to remove any substrate residue, and then dried with absorbent paper towels and placed separately in preweighed porcelain crucibles. Each set was desiccated in an oven at a temperature of $70{ }^{\circ} \mathrm{C}$, until reaching a constant weight. After determination of the respective dry weights, the crucibles were weighed once again, transferred into a muffle furnace and heated to $700{ }^{\circ} \mathrm{C}$ for two hours. Each set of crucible/ashes was weighed once again after cooling.

\section{RESULTS}

Figure 2 shows the three plants at 90 days of growth.

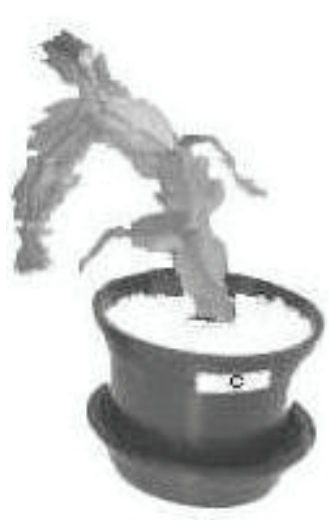

I

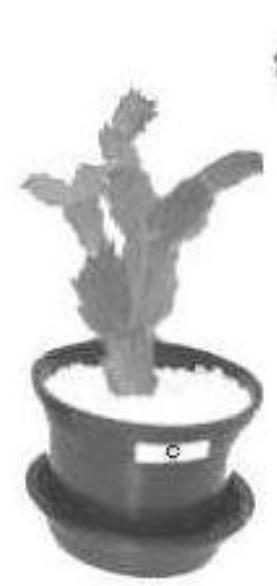

II

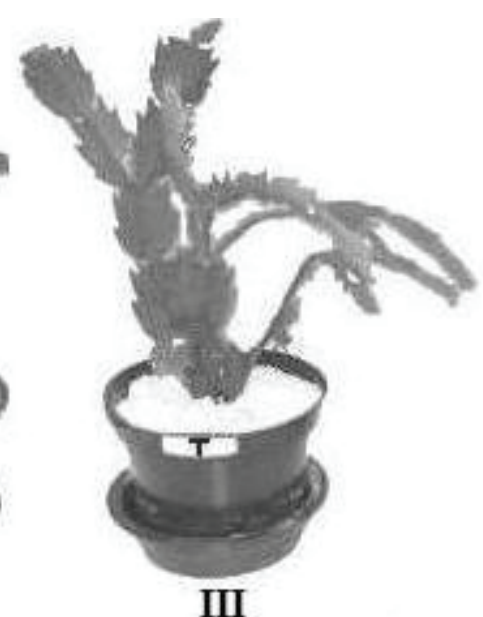

III

Figure 2. Cacti at 90 days of growth: I - Irrigated with distilled water; $\Pi$ - Irrigated with tap water; and III - Irrigated with nutrient solution.

Figura 2. Cactos com 90 dias de crescimento: I - Irrigado com água destilada; II - Irrigado com água de torneira; e III - Irrigado com solução nutritiva. 
The mean measurements obtained for each sample were calculated together with their respective standard deviations and results were compared with each other.

Student's t-test was used for these comparisons in accordance with the procedure described by Perera et al., (2010). $P$-values $<0.05$ were considered statistically significant.

The number of cladodes and the other physical parameters developed in each plant during the 90 days of cultivation are shown in Table II.

Table 2. Selected physical parameters found in the samples of cacti.

Tabela 2. Parâmetros físicos selecionados, encontrados nas amostras de cactos.

\begin{tabular}{|cccc|}
\hline & Parameters related to each plant separately & \\
\hline Treatment & Distilled water & Tap water & Nutrient solution \\
\hline Wet weight & $5.9 \mathrm{~g}$ & $15.3 \mathrm{~g}$ & $49 \mathrm{~g}$ \\
\hline Dry weight & $0.843 \mathrm{~g}$ & $1.28 \mathrm{~g}$ & $3.145 \mathrm{~g}$ \\
\hline Weight of ashes & $133 \mathrm{mg}$ & $169.6 \mathrm{mg}$ & $632 \mathrm{mg}$ \\
\hline Number of cladodes & 12 & 13 & 40 \\
\hline Mean thickness of cladodes & $0.267 \pm 0.029 \mathrm{~cm}$ & $0.336 \pm 0.029 \mathrm{~cm}$ & $0.351 \pm 0.022 \mathrm{~cm}$ \\
\hline
\end{tabular}

While the plant cultivated with tap water developed only one cladode more than the plant treated with distilled water, the plant that received the nutrient solution developed a total of forty cladodes. In addition to this growth, which was 3.1 times greater than that found in the other plants, the mean thickness of the cladodes, measured using a caliper, showed that the measurements from the plant irrigated with the nutrient solution were $32 \%$ greater than those taken from the plant treated with distilled water and $4.2 \%$ more than those taken from the plant irrigated with tap water.

The wet weight of the plant nourished with the nutrient solution was, respectively, 8.3 and 3.2 times greater than that of the plants irrigated with distilled or tap water.

Similar results were found with respect to the dry weight and the weight of the ashes. Those corresponding to the plant irrigated with the nutrient solution were proportionally greater than those obtained from the two control plants used.

Figure 3 shows the results of total chlorophyll measurements in milligrams per gram of wet weight of the samples removed from the cladodes of each individual plant.

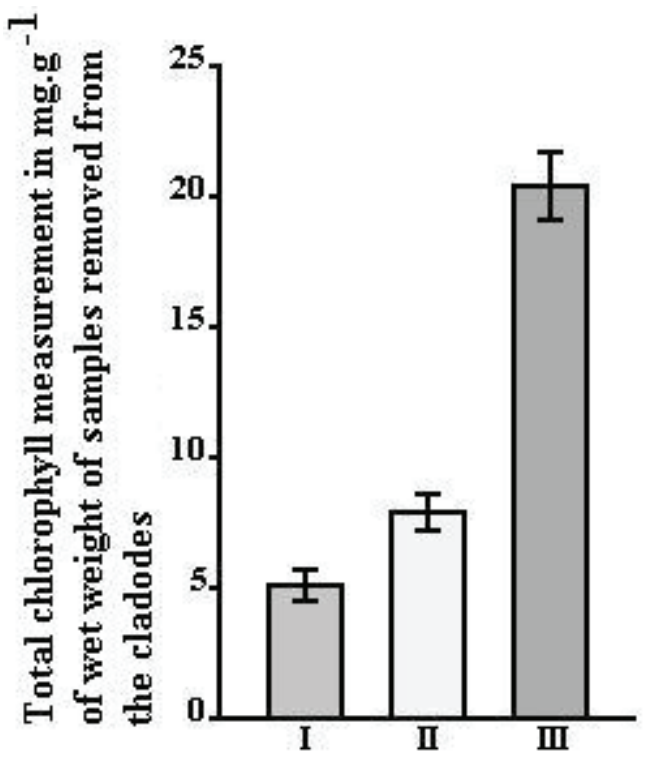

Figure 3. I - Plant treated with distilled water

\section{II - Plant treated with tap water \\ III - Plant treated with nutrient solution}

Figura 3. I - Planta tratada com água destilada; II - Planta tratada com água de torneira; III - Planta tratada com solução nutritiva. 
Total chlorophyll levels were $5.3 \pm 1.2$ and $8.0 \pm 1.3$ $\mathrm{mg} . \mathrm{g}^{-1}$ for the controls irrigated with distilled water and tap water, respectively, and $20.5 \pm 2.0 \mathrm{mg}^{-\mathrm{g}^{-1}}$ for the plant treated with the nutrient solution. The total chlorophyll level found in the plant irrigated with tap water was 1.66 times higher than that found in the plant irrigated with distilled water. This difference was statistically significant $(p<0.05)$. However, the levels found in the plant treated with the nutrient solution were 3.9 times higher than those found in the plant irrigated with distilled water and 2.6 times higher than those found in the plant treated with tap water, these differences being highly significant $(p<0.01)$.
Although the total chlorophyll levels present in the leaves of any given plant are important parameters for measuring its physiological development, principally parameters related to energy metabolism, the total protein levels in the different organs represent more sensitive evaluation tools for the detection of small physiopathological modifications and to assess plant growth.

Total protein levels, dissolved in the supernatants obtained following centrifugation at $900 \mathrm{~g}$ for $10 \mathrm{~min}$ and expressed in milligrams per gram of wet weight of the samples removed from the different plants, are shown in Figure 4.

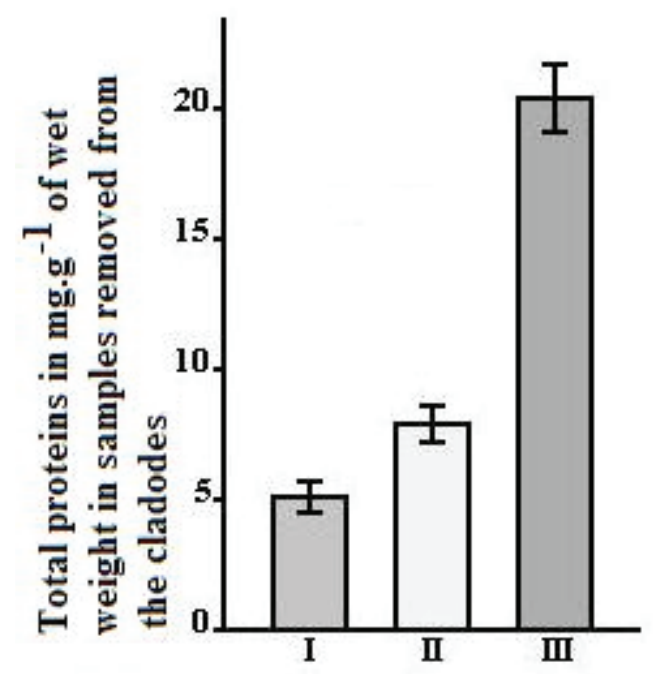

\section{Figure 4. I - Plant treated with distilled water \\ II - Plant treated with tap water \\ III - Plant treated with nutrient solution}

Figura 4. I - Planta tratada com água destilada; II - Planta tratada com água de torneira; III - Planta tratada com solução nutritiva.

Total protein levels were 4.8 times higher in the cladodes taken from the plant irrigated with the special nutrient solution compared to the plant treated with distilled water and 3.8 times higher than those measured in the cladode from the plant treated with tap water. These differences were highly significant $(\mathrm{p}<0.01)$.

\section{DISCUSSION}

The recent enthusiasm for cultivating decorative plants in public or private gardens or even in plant pots has stimulated interest in cultivating exotic plants, principally cacti and other succulents. These plants are simple to cultivate successfully. They need little care and relatively little fertilizing when planted directly into the soil and when they receive natural illumination from the sun. Nevertheless, when cultivated in restricted environments that are very different from their natural habitats, they become vulnerable and dependent, particularly on adequate illumination, controlled irrigation to avoid over-hydration of the substrate or, on the contrary, its extreme dryness, and the use of a balanced mineral fertilizer composed of macronutrients and micronutrients, which are important for its physiological growth and development (NERD and NEUMANN, 2004).

\section{CONCLUSION}

In conclusion, the exuberant growth of the $S$. truncata cactus, irrigated with this specially prepared nutrient mineral solution for 90 days of experimental treatment, encourages us to propose this solution as a mineral fertilizer for cacti and other succulents, whether confined to small, restricted environments or not. 


\section{ACKNOWLEDGEMENTS}

The authors would like to thank the Bahiana School of Medicine and Public Health, Bahiana Foundation for the Development of the Sciences (EBMSP/FBDC), Salvador, Bahia, Brazil, for making their Basic Science Laboratory available.

\section{REFERENCES}

ARNOLD, D.H.; MAUSETH, J.D. Effects of environmental factors on development of wood. American Journal of Botany, v. 86, p. 367-371, 1999.

CASTRO, J.P. Números cromossômicos em espécies de Cactáceas ocorrentes no Nordeste do Brasil. Areia, 2008. 71 p. Dissertação (Mestrado em Agronomia) Universidade Federal da Paraíba.

CORNÉLIO, V.M.D.; REIS, M.S.; SOARES, A.A.; SOARES, P.C.; OLIVEIRA, J.A. Efeito de doses e épocas de aplicação de nitrogênio na incidência de doenças, produção e qualidade sanitária das sementes de arroz. Ciências Agrotécnica, Lavras, v.31, p.47-52, 2007.

EPSTEIN, E.; BLOOM, A.J. Nutrição mineral de plantas - Princípios e perspectivas. 2 ed. Londrina: Editora Planta, 2006. 403p.

LESSA, M.A.; PAIVA, P.D.O.; ALVES, C.M.L.; RESENDE, M.L. Application of different fertilizers in substrate for Kalanchoe luciae Rayam. - Hamet cultivation. Ciências Agrotécnica, Lavras, v.33, p.950-955, 2009.

LONE, A.B.; TAKAHASHI, L.S.A.; FARIA, R.T.; UNEMOTO, L.K. Germinação de Melocactus bahiensis
(Cactaceae) em diferentes substratos e temperaturas. Scientia Agraria, Curitiba, v.8, p.365-369, 2007.

NERD, A.; NEUMANN, P.M. Phloem water transport maintains stem growth in a drought-stressed crop cactus (Hylocereus undatus). Journal American Society Horticultural Science. v.129, p.489-490, 2004.

PERERA, R.; HENEGHAN, C.; BADENOCH, D. Ferramentas estatísticas no contexto clínico. Porto Alegre: Artmed, 2010, 120p.

ROCHA, E.L.J.; AZEVEDO, B.M.; MARINHO, A.B.; CARVALHO, A.C.P.P.; VASCONCELOS, D.V.; VIANA, T.V.A. Aclimatação de mudas de helicônia em ambiente protegido em função do tipo de recipiente e do volume do substrato. Revista Brasileira de Horticultura Ornamental. v.15, n.2, p.159-163, 2009.

RODRIGUES, L.E.A.; MATHIAS, C.M.C.; AMORIM, M.S. Modificação do método de Lowry para a quantificação de proteínas. Revista Brasileira de Patologia Clínica, v.25, n.1, p.1, 1989.

RODRIGUES, L.E.A.; QUEIRES, L.C.S. Estudos fisiológicos sobre uma solução nutritiva para plantas ornamentais. Arquivos de Biologia e Tecnologia, v.38, p.883-891, 1995.

ROJAS-ARÉCHICA, M.; VÁSQUEZ-YANES, C. Cactus seed germination: a review. Journal of Arid Environments, v.44, p.85-104, 2000.

WELLBURN,A.R. The spectral determination of chlorophylls $a$ and $b$, as well as total carotenoids, using various solvents with spectrophotometers of different resolution. Journal Plant Physiology, v.144, p.307-313, 1994. 